\title{
Low risk for transmission of zoonotic Giardia duodenalis from dogs to humans in rural Cambodia
}

Tawin Inpankaew ${ }^{1,2^{*}}$, Fabian Schär ${ }^{3,4}$, Peter Odermatt ${ }^{3,4}$, Anders Dalsgaard', Wissanuwat Chimnoi ${ }^{2}$, Virak Khieu ${ }^{3,4,5}$, Sinuon Muth ${ }^{5}$ and Rebecca J Traub ${ }^{6}$

\begin{abstract}
Background: A number of epidemiological studies have demonstrated Giardia as prevalent in both humans and dogs worldwide and have postulated the occurrence of anthroponotic, zoonotic and animal-specific cycles of transmission, which may be geographically and regionally unique in its epidemiology. The aim of this study was to utilise molecular tools to determine the prevalence and compare genotypes of Giardia duodenalis infecting humans and dogs living in a previously identified Giardia-endemic village in rural Cambodia in order to ascertain zoonotic transmission risk.

Findings: The prevalence of $G$. duodenalis in humans and dogs was 18.3\% (40/218) and 10.6\% (10/94) by PCR, respectively. Molecular characterisation of the small subunit of ribosomal RNA (SSU rRNA) gene, triose phosphate isomerase (TPI) gene and sub-assemblage characterisation of the glutamate dehydrogenase (gdh) gene placed 27.5\% (11/40) of Giardia positive humans into assemblage All and 72.5\% (29/40) into assemblage Blll of G. duodenalis. In dogs, 20.0\% (2/10) of Giardia-positive samples were characterised as G. duodenalis assemblage BIII, 40.0\% (4/10) as assemblage $C$ and $40.0 \%$ (4/10) as mix infection between assemblage $C$ and $D$.
\end{abstract}

Conclusion: Overall, just over $2 \%$ of dogs harboured potentially zoonotic assemblages of G. duodenalis in the studied communities and hence pose a minimal zoonotic risk for the transmission of Giardia to humans.

Keywords: Giardia duodenalis, Humans, Dogs, Zoonosis, Cambodia

\section{Background}

Giardia is a protozoan flagellate that infects the intestinal tract of vertebrate hosts including humans and a considerable variety of other mammals through ingestion of infective cysts [1]. Among the six known Giardia species, only Giardia duodenalis has been found to infect humans and mammals. Eight distinct assemblages A to $\mathrm{H}$ have been reported and classified based on their genetic analysis and host specificity as reviewed by Ryan and Cacciò [2]. In detail, assemblages $\mathrm{A}$ and $\mathrm{B}$ can cause infection in humans and mammals, while assemblages C-G infect animals, but are occasionally found in humans.

\footnotetext{
* Correspondence: fvettwi@gmail.com

${ }^{1}$ Department of Veterinary Disease Biology, Faculty of Health and Medical

Science, University of Copenhagen, Copenhagen, Denmark

${ }^{2}$ Department of Parasitology, Faculty of Veterinary Medicine, Kasetsart

University, Bangkok, Thailand

Full list of author information is available at the end of the article
}

Moreover, assemblage $\mathrm{C}$ and $\mathrm{D}$ most commonly infect canids, assemblage E livestock, assemblage $\mathrm{F}$ cats, assemblage $\mathrm{G}$ rats and assemblage $\mathrm{H}$ marine mammals [2].

Dogs are predominantly infected with canid-specific genotypes of G. duodenalis, however may also harbour potentially zoonotic assemblages AI, AII, BIII and BIV [3]. This ability, combined with a high prevalence of infection in dogs [4] and their close association with humans, has made them a focus of attention as potentially zoonotic sources of G. duodenalis. In Cambodia, the prevalence of Giardia in humans varies from 2.9\% to $8.0 \%$ [5-8]. In rural communities, semi-domesticated dogs share a close relationship with humans providing opportunity for the transmission of G. duodenalis to humans. Yet, documentation of prevalence and genotypes of G. duodenalis in canines and humans is 
virtually inexistent in many Southeast Asian countries and Cambodia in particular.

From a public health perspective, it is necessary to distinguish G. duodenalis cysts that primarily infect dogs (assemblages $\mathrm{C}$ and $\mathrm{D}$ ) from those that have zoonotic potential (assemblages A and B), and this can only be based on their discrimination using a multilocus molecular typing approach [9].

In May 2012, a total of 40/218 (18.4\%) of humans from 67 households in Dong village, Preah Vihear province, Cambodia were found positive for Giardia by PCR targeting the SSU rRNA gene of G. duodenalis. In dogs, the prevalence of Giardia using zinc sulphate centrifugal flotation was $2.1 \%(2 / 94)$ [10]. The objective of this study was to utilise more sensitive molecular tools to screen for the presence of G. duodenalis in dogs living in the same village and a multilocus genotyping approach to assess the risk for zoonotic transmission.

\section{Methods}

\section{Study area, design and field procedures}

For detailed information on study design and parasitological methods, refer to the study by Schär et al. [10]. Briefly, in May 2012, a total of 218 human and 94 dog faecal samples were collected from 67 households in Dong village, Rovieng district, Preah Vihear province, Cambodia (13.410842 N, 105.128217 E). This research was approved by the Ethics Committee of the Cantons of Basel-Stadt and Baselland, Switzerland, (EKBB, \#18/ 12, dated 23 February 2012), and by the National Ethics Committee for Health Research, Ministry of Health, Cambodia (NECHR, \#192, dated 19 November 2011). All studies with animals involved were done following the European Convention for the "Protection of Vertebrate Animals used for Experimental and Other Scientific Purposes". Animals were handled with respect according to the laws on experimental animal care in Cambodia. All samples were transported at room temperature by TNT Express worldwide to the School of Veterinary Science, University of Queensland, Gatton campus, Australia for further analysis. All faecal samples were examined microscopically for the presence of G. duodenalis cysts using zinc sulphate centrifugal flotation. In addition, risk factors for infection of humans and animals were assessed by questionnaire interviews with participants and head of households.

\section{DNA extraction}

Dog faecal samples fixed in $2.5 \%$ potassium dichromate were subjected to DNA extraction regardless of Giardia status by microscopy, using PowerSoil DNA Kit (Mo Bio, CA, USA). The extraction was performed according to manufacturer's instructions with minor modification. ZIRCONIA/SILICA beads $0.5 \mathrm{~mm}$ in diameter (BioSpec product Inc, USA) were used instead of the PowerBead provided by the manufacturer. Samples were disrupted using a Mini-BeadBeater-16 (BioSpec product Inc, USA) at maximum speed for $5 \mathrm{~min}$. The DNA was stored at $-20^{\circ} \mathrm{C}$ until used for PCR amplification.

\section{Molecular analysis \\ The small subunit rDNA gene}

A previously published nested PCR was utilised to screen dog faecal samples for Giardia by targeting a 174 bp fragment of the SSU rDNA gene of G. duodenalis [11,12]. Briefly, the PCR was carried out in $25 \mu \mathrm{l}$ volumes with each final reaction containing $1 \times$ CoralLoad PCR buffer (Qiagen Pty Ltd.), 12.5 pmol of each primer, $0.5 \mathrm{U}$ of HotStar Taq DNA polymerase (Qiagen Pty Ltd.) and $2 \mu \mathrm{l}$ of DNA. The cycling conditions were the same as the published protocol except for an initial denaturation of $5 \mathrm{~min}$ at $95^{\circ} \mathrm{C}$. Dog and human [10] samples positive for G. duodenalis on the SSU rDNA gene were further characterised at the TPI gene.

\section{The triose phosphate isomerase (TPI) gene}

For humans, a pan-assemblage nested PCR targeting a $530 \mathrm{bp}$ region of the TPI gene [13] and for dogs, an additional assemblage $\mathrm{C}$ - and $\mathrm{D}$ - specific PCR assay targeting a region of the TPI gene [14] was utilised to genotype G. duodenalis positive samples. The PCR was carried out in $25 \mu \mathrm{l}$ volumes with each final reaction containing 1x CoralLoad PCR buffer (Qiagen Pty Ltd.), 12.5 pmol of each primer, $0.5 \mathrm{U}$ of HotStar Taq DNA polymerase (Qiagen Pty Ltd.) and $2 \mu \mathrm{l}$ of DNA. The cycling conditions were the same as the published protocol except for an initial denaturation of $5 \mathrm{~min}$ at $95^{\circ} \mathrm{C}$. For all PCR assays, a positive control of G. duodenalis and a negative control of distilled water were included in each run.

\section{The glutamate dehydrogenase ( $g d h)$ gene}

Dogs and humans positive for G. duodenalis assemblage $\mathrm{A}$ and $\mathrm{B}$ at the SSU rDNA and TPI genes were further genotyped at a $530 \mathrm{bp}$ region of the gdh gene using a previously published nested PCR assay [15]. The PCR cycling conditions were the same as the published protocol.

\section{DNA sequencing}

PCR positive samples of the correct size for the SSU rRNA, TPI and gdh genes of G. duodenalis were subjected to DNA sequencing. The PCR products were purified using PureLink quick PCR purification kit (Life Technologies, Invitrogen, Eugene, USA) according to manufacturer's protocol and submitted to the University of Queensland Animal Genetic Laboratory for sequencing using both forward and reverse primers. DNA sequences were visualised using Finch TV 1.4.0 (Geospiza, Inc.) and aligned 
using BioEdit version 7.2.0 (www.mbio.ncsu.edu/BioEdit/bioedit.html) and directly compared with reference isolates of the TPI and gdh genes of G. duodenalis assemblages A-E.

\section{Statistical analysis}

The data was double entered and validated in Epidata (www.epidata.dk). Analysis was carried out using STATA version 12 (StataCorp ltd.). Infection prevalence rates were calculated. $X^{2}$ test was used to associate infection status with risk factors. A p-value $<0.05$ was considered significant.

\section{Results and discussion}

A number of studies have demonstrated G. duodenalis as prevalent in both humans and dogs worldwide and have postulated the occurrence of anthroponotic, zoonotic and animal-specific cycles of transmission [9], which may be geographically and regionally unique in its epidemiology [16]. This study represents the first detailed report on zoonotic aspects of canine Giardia infections in Cambodia. The prevalence of Giardia duodenalis infection in human and dog samples by microscopic analysis and molecular analysis from Cambodia are displayed in Table 1. The prevalence among dogs of $2.1 \%$ by microscopy [10] and $10.6 \%$ by PCR is comparable to those encountered in rural communities in northeast India [17]. The primary difference between the two settings is that in Dong village, it would appear that the risk of dogs as a source of zoonotic Giardia is negligible. In dogs, 40.0\% (4/10) of G. duodenalis positive samples were characterized as assemblage C, $40.0 \%(4 / 10)$ as mix infection between assemblage $C$ and D and $20.0 \%$ $(2 / 10)$ as assemblage BIII (Table 1$)$. Overall, this placed $2 / 94$ dogs $(2.1 \%)$ as harbouring potentially zoonotic assemblages of G. duodenalis (Table 2). This is in contrast to other surveys in rural China, rural India, Spain and indigenous communities of Saskatchewan, in which assemblage A was the predominant zoonotic assemblage encountered in dogs [4,18-20].
Table 2 Summary of genotype results of Giardia isolates recovered from dogs at three different loci

\begin{tabular}{lccccc}
\hline $\begin{array}{l}\text { Dog } \\
\text { isolate }\end{array}$ & $\begin{array}{c}\text { SSU } \\
\text { rRNA }\end{array}$ & $\begin{array}{c}\text { TPI (broad } \\
\text { specificity) }\end{array}$ & $\begin{array}{c}\text { TPI (dog } \\
\text { specificity) }\end{array}$ & gdh & $\begin{array}{c}\text { Human } \\
\text { isolate }\end{array}$ \\
\hline H15D1 & C & $C$ & $C$ & NA & \\
H17D1 & $C$ & $C$ & $C$ & NA & \\
H27D3 & $C$ & $C$ & $D$ & NA & \\
H28D7 & $C$ & $C$ & $D$ & NA & \\
H31D1 & $C$ & $C$ & $D$ & NA & \\
H32D1 & $C$ & $C$ & $C$ & NA & \\
H34D4 & $C$ & $C$ & $D$ & NA & \\
H36D1 & $B$ & $B$ & $B$ & $B I I I$ & H36H1 \\
H37D1 & $B$ & $B$ & $B$ & BIII & \\
H37D3 & $C$ & $C$ & $C$ & NA & \\
\hline
\end{tabular}

NA: not applicable.

Among humans, the prevalence of G. duodenalis was $18.4 \%$ by PCR screening of the SSU rRNA gene, surpassing the microscopy-based prevalence of $9.2 \%$ described by Schär et al. [10]. Genetic characterisation placed $72.5 \%$ (29/40) of $G$. duodenalis as assemblage BIII and 11/40 (27.5\%) as assemblage AII (Table 3). These results suggest that separate anthroponotic and dog-specific cycles of $G$. duodenalis exist within Dong village in Cambodia, with negligible potential for human-dog cross-transmission. Shared environments among dogs with indiscriminate defecation patterns are hypothesised to be conducive for the transmission of the canid-specific genotypes of the parasite $[21,22]$, as is the case for free roaming dogs in Dong village. Nevertheless, the opportunity for dogs to be exposed to human faeces within Dong village was still evident, reflected by just over half the human population utilising latrines [10]. This could have potentially accounted for the two dogs found to harbour $G$. duodenalis assemblage BIII genotypes, the predominant genotype in humans within the village. Whether these animals were indeed infected or just mechanically passing Giardia present in human faeces via coprophagy remains unknown.

Table 1 The prevalence of Giardia duodenalis infection in human and dog samples by microscopic analysis and molecular analysis from Cambodia

\begin{tabular}{|c|c|c|c|c|c|c|}
\hline $\begin{array}{l}\text { Tests/ } \\
\text { species }\end{array}$ & $\begin{array}{l}\text { Total no. } \\
\text { of samples }\end{array}$ & $\begin{array}{c}\text { Positive } \\
\text { samples (\%) }\end{array}$ & Assemblage A (\%) & Assemblage B (\%) & Assemblage C (\%) & Assemblage D (\%) \\
\hline \multicolumn{7}{|l|}{ Microscopic } \\
\hline Humans & 218 & $20(9.2)^{*}$ & NA & NA & NA & NA \\
\hline Dogs & 94 & $2(2.1)$ & NA & NA & NA & NA \\
\hline \multicolumn{7}{|l|}{ PCR } \\
\hline Humans & 218 & $40(18.4)^{*}$ & $11(27.5)$ & $29(72.5)$ & - & - \\
\hline Dogs & 94 & $10(10.6)$ & - & $2(20.0)$ & $4(40.0)$ & $4(40.0)$ \\
\hline
\end{tabular}

NA: not applicable, *Published by Schär et al. [10]. 
Table 3 Summary of genotype results of Giardia isolates recovered from humans at three different loci (A dash indicates unsuccessful PCR amplification or sequencing of the isolate)

\begin{tabular}{|c|c|c|c|}
\hline Human isolate & SSU rRNA & TPI & gdh \\
\hline $\mathrm{H} 03 \mathrm{H} 1$ & B & B & BIII \\
\hline $\mathrm{H} 05 \mathrm{H} 3$ & B & B & BIII \\
\hline $\mathrm{H} 05 \mathrm{H} 4$ & B & B & BIII \\
\hline $\mathrm{H} 07 \mathrm{H} 1$ & B & B & BIII \\
\hline $\mathrm{H} 16 \mathrm{H} 1$ & B & B & BIII \\
\hline $\mathrm{H} 16 \mathrm{H} 3$ & B & B & BIII \\
\hline $\mathrm{H} 16 \mathrm{H} 4$ & B & B & BIII \\
\hline $\mathrm{H} 18 \mathrm{H} 3$ & B & B & BIII \\
\hline $\mathrm{H} 2 \mathrm{OH} 4$ & B & B & BIII \\
\hline $\mathrm{H} 22 \mathrm{H} 5$ & B & B & BIII \\
\hline $\mathrm{H} 25 \mathrm{H} 3$ & B & B & BIII \\
\hline $\mathrm{H} 26 \mathrm{H} 2$ & B & B & BIII \\
\hline $\mathrm{H} 27 \mathrm{H} 1$ & B & B & BIII \\
\hline $\mathrm{H} 31 \mathrm{H} 4$ & B & B & BIII \\
\hline $\mathrm{H} 35 \mathrm{H} 1$ & B & B & BIII \\
\hline $\mathrm{H} 36 \mathrm{H} 1$ & B & B & BIII \\
\hline $\mathrm{H} 41 \mathrm{H} 1$ & B & B & BIII \\
\hline D0112-02 & B & B & BIII \\
\hline D0124-03 & B & B & BIII \\
\hline D0124-06 & B & B & BIII \\
\hline D0126-01 & B & B & BIII \\
\hline D0126-03 & B & B & BIII \\
\hline D0130-02 & B & B & BIII \\
\hline D0132-05 & B & B & BIII \\
\hline D0134-03 & B & B & BIII \\
\hline D0135-03 & B & B & BIII \\
\hline D0140-03 & B & B & BIII \\
\hline D0141-03 & B & B & BIII \\
\hline D0144-02 & B & B & BIII \\
\hline $\mathrm{H} 06 \mathrm{H} 1$ & A & A & All \\
\hline $\mathrm{H} 07 \mathrm{H} 5$ & A & A & All \\
\hline $\mathrm{H} 08 \mathrm{H} 2$ & A & A & - \\
\hline $\mathrm{H} 17 \mathrm{H} 4$ & A & A & All \\
\hline $\mathrm{H} 22 \mathrm{H} 3$ & A & A & All \\
\hline $\mathrm{H} 40 \mathrm{H} 4$ & A & A & All \\
\hline D0095-02 & A & A & All \\
\hline D0119-04 & A & A & All \\
\hline D0123-03 & A & A & All \\
\hline D0140-04 & A & A & All \\
\hline D0142-06 & A & A & - \\
\hline
\end{tabular}

In this context it is important to note that multiintestinal parasitic infections are highly frequent in Cambodia. In Dong village more than half of the village population harbours two or more intestinal parasitic infections concurrently. The same is true for dogs of the same households [10]. Interestingly, dogs in this village are known to contribute to the contamination of the environment with zoonotic parasites reflected by the highly prevalent nature of Ancylostoma ceylanicum in humans and dogs [23].

Age was the only factor that was significantly associated with the prevalence of Giardia in both humans [10] and dogs. The prevalence of $G$. duodenalis using PCR was significantly higher in young dogs up to 12 months of age $(20.0 \%)$ compared to older $\operatorname{dogs}(3.7 \%, \mathrm{p}=0.02)$, a factor consistently observed in previous epidemiological studies $[3,21,24]$. Age increased immunity towards the parasite and risk-based exposures to infection are the most likely explanations for this observation.

This study confirms the advantage of utilising the assemblage C- and D-specific PCR [14] for targeting the TPI gene of G. duodenalis in dogs. Four out of 8 (50.0\%) isolates from dogs classified as assemblage $\mathrm{C}$ using the $18 \mathrm{~S}$ rRNA and the pan-assemblage PCR targeting the TPI [25] gene were classified as assemblage D using the assemblage $\mathrm{C}$ and $\mathrm{D}$-specific assay (Table 3 ). As previously observed $[9,14]$, these are likely due to mismatches in the binding regions of the primers and most likely represent mixed assemblage $\mathrm{C}+\mathrm{D}$ infections in these animals. However, the potential ability of G. duodenalis to undergo recombination between isolates from different assemblages may also account for this finding [26].

\section{Conclusion}

This work contributes to the understanding of G. duodenalis transmission in human and dog populations living closely together in small rural communities in Cambodia and concludes that in rural Cambodia, community dogs play a negligible role as zoonotic reservoirs for Giardia.

\section{Competing interests}

The authors declare that they have no competing interests.

\section{Authors' contributions}

Conceived and designed the experiments: TI PO AD RJT. Performed the experiments: TI FS WC VK MS. Analysed the data: TI FS PO AD RJT. Contributed reagent/materials/analysis tools: VK PO AD RJT. Wrote the manuscript: TI FS PO $A D$ RJT. All authors read and approved the final version of the manuscript.

\section{Acknowledgements}

The authors gratefully acknowledge staff from the National Centre for Parasitology, Entomology and Malaria Control, Cambodia for their help in collecting faecal samples from human and dogs as well as with the interviews. We also thank Dr. Chhay Somany, deputy director of the provincial health department at Preah Vihear province for his hospitality during sample collection and Prof. K. Darwin Murrell, for his guidance and valuable discussions throughout this study. Special thanks got to all study participants and their dogs at the Dong village. 


\section{Financial support}

FS, VK and SM were supported by the UBS Optimus Foundation. TI was supported by a PhD fellowship grant from the Faculty of Health and Medical Sciences, University of Copenhagen, Denmark.

\section{Author details}

${ }^{1}$ Department of Veterinary Disease Biology, Faculty of Health and Medical Science, University of Copenhagen, Copenhagen, Denmark. ${ }^{2}$ Department of Parasitology, Faculty of Veterinary Medicine, Kasetsart University, Bangkok, Thailand. ${ }^{3}$ Swiss Tropical and Public Health Institute, Basel, Switzerland. ${ }^{4}$ University of Basel, Basel, Switzerland. ${ }^{5}$ National Center for Parasitology, Entomology and Malaria Control, Phnom Penh, Cambodia. ${ }^{6}$ Faculty of Veterinary and Agricultural Sciences, The University of Melbourne, Parkville, Victoria, Australia.

Received: 13 May 2014 Accepted: 19 August 2014

Published: 29 August 2014

\section{References}

1. van der Giessen JW, de Vries A, Roos M, Wielinga P, Kortbeek LM, Mank TG: Genotyping of Giardia in Dutch patients and animals: a phylogenetic analysis of human and animal isolates. Int J Parasitol 2006, 36:849-858.

2. Ryan U, Cacciò SM: Zoonotic potential of Giardia. Int J Parasitol 2013, 43:943-956.

3. Inpankaew T, Traub R, Thompson RC, Sukthana Y: Canine parasitic zoonoses in Bangkok temples. Southeast Asian J Trop Med Public Health 2007, 38:247-255.

4. Traub RJ, Monis PT, Robertson I, Irwin P, Mencke N, Thompson RC: Epidemiological and molecular evidence supports the zoonotic transmission of Giardia among humans and dogs living in the same community. Parasitology 2004, 128:253-262.

5. Lee KJ, Bae YT, Kim DH, Deung YK, Ryang YS, Kim HJ, Im KI, Yong TS: Status of intestinal parasites infection among primary school children in Kampongcham, Cambodia. Korean J Parasitol 2002, 40:153-155.

6. Park SK, Kim DH, Deung YK, Kim HJ, Yang EJ, Lim SJ, Ryang YS, Jin D, Lee KJ: Status of intestinal parasite infections among children in Bat Dambang, Cambodia. Korean J Parasitol 2004, 42:201-203.

7. Chhakda T, Muth S, Socheat D, Odermatt P: Intestinal parasites in school-aged children in villages bordering Tonle Sap Lake, Cambodia. Southeast Asian J Trop Med Public Health 2006, 37:859-864.

8. Moore CE, Hor PC, Soeng S, Sun S, Lee SJ, Parry CM, Day NP, Stoesser N: Changing patterns of gastrointestinal parasite infections in Cambodian children: 2006-2011. J Trop Pediatr 2012, 58:509-512.

9. Beck R, Sprong H, Pozio E, Cacciò SM: Genotyping Giardia duodenalis isolates from dogs: lessons from a multilocus sequence typing study. Vector Borne Zoonotic Dis 2012, 12:206-213.

10. Schär F, Inpankaew T, Traub RJ, Khieu V, Dalsgaard A, Chimnoi W, Chamnan C, Sok D, Marti H, Muth S, Odermatt P: The prevalence and diversity of intestinal parasitic infections in humans and domestic animals in a rural Cambodian village. Parasitol Int 2014, 63:597-603.

11. Hopkins RM, Meloni BP, Groth DM, Wetherall JD, Reynoldson JA, Thompson RC: Ribosomal RNA sequencing reveals differences between the genotypes of Giardia isolates recovered from humans and dogs living in the same locality. J Parasitol 1997, 83:44-51.

12. Read C, Walters J, Robertson ID, Thompson RC: Correlation between genotype of Giardia duodenalis and diarrhoea. Int J Parasitol 2002, 32:229-231.

13. Sulaiman IM, Fayer R, Bern C, Gilman RH, Trout JM, Schantz PM, Das P, Lal AA, Xiao L: Triosephosphate isomerase gene characterization and potential zoonotic transmission of Giardia duodenalis. Emerg Infect Dis 2003, 9:1444-1452.

14. Lebbad M, Mattsson JG, Christensson B, Ljungström B, Backhans A, Andersson JO, Svärd SG: From mouse to moose: multilocus genotyping of Giardia isolates from various animal species. Vet Parasitol 2010, 168:231-239.

15. Cacciò SM, Beck R, Lalle M, Marinculic A, Pozio E: Multilocus genotyping of Giardia duodenalis reveals striking differences between assemblages A and B. Int J Parasitol 2008, 38:1523-1531.

16. Ballweber LR, Xiao L, Bowman DD, Kahn G, Cama VA: Giardiasis in dogs and cats: update on epidemiology and public health significance. Trends Parasitol 2010, 26:180-189.
17. Traub RJ, Inpankaew T, Reid SA, Sutthikornchai C, Sukthana Y, Robertson ID, Thompson RC: Transmission cycles of Giardia duodenalis in dogs and humans in Temple communities in Bangkok-a critical evaluation of its prevalence using three diagnostic tests in the field in the absence of a gold standard. Acta Trop 2009, 111:125-132.

18. Dado D, Montoya A, Blanco MA, Miró G, Saugar JM, Bailo B, Fuentes I: Prevalence and genotypes of Giardia duodenalis from dogs in Spain: possible zoonotic transmission and public health importance. Parasitol Res 2012, 111:2419-2422.

19. Liu A, Zhang X, Zhang L, Wang R, Li X, Shu J, Zhang X, Shen Y, Zhang W, Ling $\mathrm{H}$ : Occurrence of bovine giardiasis and endemic genetic characterization of Giardia duodenalis isolates in Heilongjiang Province, in the Northeast of China. Parasitol Res 2012, 111:655-661.

20. Schurer JM, Hill JE, Fernando C, Jenkins EJ: Sentinel surveillance for zoonotic parasites in companion animals in indigenous communities of Saskatchewan. Am J Trop Med Hyg 2012, 87:495-498.

21. Mark-Carew MP, Adesiyun AA, Basu A, Georges KA, Pierre T, Tilitz S, Wade SE, Mohammed HO: Characterization of Giardia duodenalis infections in dogs in Trinidad and Tobago. Vet Parasitol 2013, 196:199-202.

22. Solarczyk P, Majewska AC: A survey of the prevalence and genotypes of Giardia duodenalis infecting household and sheltered dogs. Parasitol Res 2010, 106:1015-1019.

23. Inpankaew T, Schär F, Dalsgaard A, Khieu V, Chimnoi W, Chhoun C, Sok D, Marti H, Muth S, Odermatt P, Traub RJ: High prevalence of Ancylostoma ceylanicum hookworm infections in humans, Cambodia, 2012. Emerg Infect Dis 2014, http://dx.doi.org/10.3201/eid2006.131770.

24. Mohamed AS, Glickman LT, Camp JW Jr, Lund E, Moore GE: Prevalence and risk factors for Giardia spp. infection in a large national sample of pet dogs visiting veterinary hospitals in the United States (2003-2009). Vet Parasitol 2013, 195:35-41.

25. Sulaiman IM, Jiang J, Singh A, Xiao L: Distribution of Giardia duodenalis genotypes and subgenotypes in raw urban wastewater in Milwaukee, Wisconsin. Appl Environ Microbiol 2004, 70:3776-3780.

26. Cooper MA, Sterling CR, Gilman RH, Cama V, Ortega Y, Adam RD: Molecular analysis of household transmission of Giardia lamblia in a region of high endemicity in Peru. J Infect Dis 2010, 202:1713-1721.

\section{doi:10.1186/1756-3305-7-412}

Cite this article as: Inpankaew et al: Low risk for transmission of zoonotic Giardia duodenalis from dogs to humans in rural Cambodia. Parasites \& Vectors 2014 7:412

\section{Submit your next manuscript to BioMed Central and take full advantage of:}

- Convenient online submission

- Thorough peer review

- No space constraints or color figure charges

- Immediate publication on acceptance

- Inclusion in PubMed, CAS, Scopus and Google Scholar

- Research which is freely available for redistribution 